\title{
DNM1 L wt Allele
}

National Cancer Institute

\section{Source}

National Cancer Institute. DNM1L wt Allele. NCI Thesaurus. Code C116996.

Human DNM1L wild-type allele is located in the vicinity of 12p11.21 and is approximately $66 \mathrm{~kb}$ in length. This allele, which encodes dynamin-1-like protein, is involved in the division process of both mitochondria and peroxisomes. Mutation of the gene is associated with lethal encephalopathy due to defective mitochondrial peroxisomal fission. 